\title{
Teacher's Perception on the Application of Scientific Approach in Learning of Arabic in Islamic Boarding Schools
}

\author{
Nurlaila $^{1 *}$, Kamaluddin ${ }^{2}$ \\ ${ }^{1}$ Arabic Education Study Program Institut Agama Islam Negeri Batusangkar, Indonesia \\ ${ }^{2}$ Arabic Education Study Program Institut Agama Islam Negeri Batusangkar, Indonesia
}

\section{Article History:}

Received : August 07, 2019

Revised : September 18, 2019

Accepted : October 26, 2019

Published : December 01, 2019

\section{Keywords:}

Competence; Implementation; Policy; Various Trainings

\section{*Correspondence Address:} nurlaila@iainbatusangkar.ac.id

\begin{abstract}
The scientific approach has been applied in learning Arabic in schools/madrasah throughout Indonesia over the past few years. However, this is not the case in Islamic boarding schools, not all Islamic boarding schools apply this scientific approach in learning Arabic. This research aims to reveal the teacher's perception of the application of scientific approaches in learning Arabic in Islamic boarding schools. The research method used was a survey method. The research sample consisted of 20 Islamic boarding schools in the province of West Sumatra. Research data were collected through a questionnaire filled out by Arabic language teachers in the Islamic boarding schools. The data analysis technique is descriptive quantitative analysis using percentages. The results showed that the majority of teachers agreed with the application of the scientific approach in learning Arabic in Islamic boarding schools since the majority of teachers perceive that the scientific approach is appropriate and effective to be used in learning Arabic. However, some teachers still find difficulties in implementing it even though they have participated in various trainings. In addition, not all Islamic boarding schools are equipped with adequate infrastructure to support the implementation of a scientific approach. Therefore, it is needed a policy from the authorities to improve teacher competence and complete facilities for the implementation of scientific approach in learning Arabic in Islamic boarding schools.
\end{abstract}

\section{Introduction}

Learning with a scientific approach is learning that adopts scientific steps in building knowledge through scientific methods. In the learning process, the scientific approach touches on three domains, namely attitudes, knowledge, and skills. The realm of attitude includes the transformation of teaching material so that students "know why", the realm of knowledge covers the transformation of teaching material so that students "know what", and the realm of skills encompassing the transformation of teaching material so that students "know how". 
The scientific approach has been implemented in learning for students in Indonesia. Various studies on scientific approaches have been carried out. They are about implementation of scientific approach in learning ${ }^{1}$, the competence of the teacher in scientific learning ${ }^{2}$, the pre-service teachers' practices in implementing scientific approach $^{3}$, the scientific learning instruments ${ }^{4}$, effects of scientific approach on learning outcomes ${ }^{5}$, and about the effects of scientific approach on various skills ${ }^{6}$.

In learning Arabic, the application of a scientific approach is actually still being debated. According to Ainin ${ }^{7}$, based on an analysis of the nature of language learning especially Arabic for beginners, and the results of the analysis of the characteristics of a scientific approach that is scientific and less rooted in linguistic theories and psychology of language learning, the scientific approach is less relevant and less applicable to implemented in learning Arabic. According to Ainin, language learning, especially

${ }^{1}$ Diki Atmarizon, \& M. Zaim, 'The Implementation of Scientific Approach in Teaching English at the Tenth Grade of Senior High School 7 Padang', Komposisi: Jurnal Pendidikan Bahasa, Sastra, dan Seni, 2016, 17(1); M. Zaim, 'Implementing Scientific Approach to Teach English at Senior High School in Indonesia', Asian Social Science, 2017, 13(2); R. Susanti, Y. Anwar, \& Ermayanti, 'Implementation of Learning Based on Scientific Approach to Improve Science Process Skills of Biology Education Students in General Biology Course', Journal of Physics: Conference Series, 2019, 1166(1); Ro'is Indriawan, Achmad Slamet, \& Kardoyo, 'Implementation of Scientific Approach in Economic Learning', Journal of Economic Education, 2018, 7(1); Sri Ratnaningsih, 'Scientific Approach of 2013 Curriculum: Teachers' Implementation in English Language Teaching', English Review: Journal of English Education, 2017, 6(1); Wahyono, Ishak Abdulhak, \& Rusman, 'Implementation of Scientific Approach Based Learning to Think High Levels in State Senior High School in Ketapang', International Journal of Education and Research, 2017, 5(8).

${ }^{2}$ E. Ningrum, 'Mapping of Pedagogic Competency of Geography Teacher in Scientific Learning Based-On Curriculum 2013', IOP Conference Series: Earth and Environmental Science, 2019, 286(1).

3 Endang Susantini, I. Kurniasari, A. N. M. Fauziah, T. Prastowo, A. Kholiq, \& L. Rosdiana, 'Engaging Pre-Service Teachers to Teach Science Contextually with Scientific Approach Instructional Video', IOP Conference Series: Materials Science and Engineering, 2018, 296; Rina Astuti Purnamaningwulan, 'Pre-Service Teachers' Reflective Practices in Implementation the Scientific Aproach of 2013 Curriculum', International Journal of Indonesian Education and Teaching, 2019, 3(2).

${ }^{4}$ D. Setiawan \& I. Wilujeng, 'The Development of Scientific-Approach-Based Learning Instruments Integrated with Red Onion Farming Potency in Brebes Indonesia', Jurnal Pendidikan IPA Indonesia, 2016, $5(1)$.

${ }^{5}$ Firman, Baedhowi, \& Wiedy Murtini, 'The Effectiveness of The Scientific Approach to Improve Student Learning Outcomes', International Journal of Active Learning, 2018, 3(2).

6 Sekar Purbarini Kawuryan, Woro Sri Hastuti, \& Supartinah, 'Pengaruh Model Pembelajaran Tematik Berbasis Permainan Tradisional dan Scientific Approach terhadap Kemampuan Berpikir Kreatif', Cakrawala Pendidikan, 2018, 37(1); R. E. Safitri \& D. B. Widjajanti, 'The Effect of Inquiry in Scientific Learning on Students' Self-Confidence', Journal of Physics: Conference Series, 2019, 1157(4); R. Susanti, Y. Anwar, \& Ermayanti, 'Implementation of Learning Based on Scientific Approach to Improve Science Process Skills of Biology Education Students in General Biology Course', Journal of Physics: Conference Series, 2019, 1166(1).

7 Moh. Ainin, 'Implementasi Pendekatan Saintifik di Era Kurikulum URIKULUM 13 dalam Pembelajaran Bahasa Arab: Relevankah?', Proceeding, Konferensi Nasional Bahasa Arab III, 2017, Malang. 
Arabic, has its own approach adopted from both linguistic theory and learning psychology.

Although there is still debate, however in fact a scientific approach has been applied in learning Arabic in Indonesia. The Arabic curriculum is designed in such a way that suits the learning framework of a scientific approach. Arabic teachers are given training so that they can implement a scientific approach. Textbooks were transformed into textbooks based on a scientific approach. Various workshops and discussion forums were held to bring together an understanding of the application of the scientific approach.

The scientific approach has been applied for the past several years. Much research has been done related to teacher perceptions of the application of scientific approaches in several subjects, such as teacher perceptions of the application of scientific approaches in Indonesian $^{8}$, Japanese ${ }^{9}$, and English ${ }^{10}$. The research on teacher perceptions related to the application of scientific approaches in Arabic subjects has not been found at all.

Research on scientific approaches in Arabic subjects that have been carried out is only limited to the application of the scientific approach. However, research has not yet been found on the application of scientific approaches in learning Arabic in Islamic boarding schools. Existing research is only about the application of scientific approaches in learning Arabic in basic education ${ }^{11}$ and secondary ${ }^{12}$, while research on the application of scientific approaches in learning Arabic in Islamic boarding schools has not been found. Researches about learning Arabic in Islamic boarding schools are more researching about Arabic learning models in Islamic boarding schools ${ }^{13}$, Arabic learning

${ }^{8}$ Prima Gusti Yanti, Nini Ibrahim, \& Fauzi Rahman, 'Persepsi Guru terhadap Pendekatan Saintifik pada Kurikulum 2013 dalam Proses Belajar Mengajar', Faktor: Jurnal Ilmiah Kependidikan, 2018, 5(1).

${ }^{9}$ Kadek Eva Krishna Adnyani, Ni Wayan Surya Mahayanti, \& G. A. P. Suprianti, 'Persepsi Guru Bahasa Jepang di Kabupaten Buleleng Terhadap Penerapan Pendekatan Saintifik dalam Implementasi Kurikulum 2013', SEMINAR NASIONAL RISET INOVATIF III, 2015, Singaraja Bali: Lembaga Penelitian Universitas Pendidikan Ganesha.

${ }^{10}$ Djuwariyah Ahmad \& Mardiana, 'Kurikulum 2013 dalam Persepsi dan Interpretasi Guru Bahasa Inggris SMA Kota Makassar', BAHTERA: Jurnal Pendidikan Bahasa dan Sastra, 2014, 13(1).

11 Azkia Muharom Albantani, 'Implementasi Kurikulum 2013 pada Pembelajaran Bahasa Arab di Madrasah Ibtidaiyah', Arabiyat: Jurnal Pendidikan Bahasa Arab dan Kebahasaaraban, 2015, 2(2); Anwar Sadat, 'Pendekatan Saintifik dalam Pembelajaran Bahasa Arab di Madrasah Ibtidaiyah Berbasis Kurikulum 2013', EL-Muhbib: Jurnal Pemikiran dan Penelitian Pendidikan Dasar, 2017, 1(2).

12 Binti Khoirunnisak, 'Implementasi Pendidikan Saintifik dalam Pembelajaran Bahasa Arab', Al Mahāra Jurnal Pendidikan Bahasa Arab, 2016, 2(1).

13 Nurul Hanani, 'Model Pembelajaran Bahasa Arab di Pondok Pesantren Salaf Kediri dan Kontribusinya terhadap Kemampuan Membaca Teks Berbahasa Arab bagi Santri', Realita, 2015, 13(1). 
methods in Islamic boarding schools ${ }^{14}$, modernization of Arabic learning in Islamic boarding schools ${ }^{15}$ and others. Thus, research on the scientific approach in learning Arabic in the Islamic boarding schools has not been carried out at all, both related to the teacher's perception or related to the application of the scientific approach.

Thus, research on scientific approaches in learning Arabic in Islamic boarding schools is very important, both those related to the perceptions of the teachers and those related to their application. In this study, researchers conducted a survey of Arabic language teachers in Islamic boarding schools regarding their perceptions about the application of scientific approaches in learning Arabic in Islamic boarding schools.

\section{Theoretical Support}

\section{Scientific Approach}

The scientific approach is a learning process that is designed so that participants actively construct concepts, laws, or principles through observing, formulating problems, proposing and formulating hypotheses, collecting data with various techniques, analyzing data, drawing conclusions, and communicating ${ }^{16}$. The application of a scientific approach aims at understanding students in getting to know, understanding various materials using a scientific approach, that information can come from anywhere, anytime, not dependent on unidirectional information from teachers ${ }^{17}$. The learning objectives with a scientific approach include: (1) improving intellectual abilities, specifically students' higher-order thinking skills, (2) forming students' ability to solve problems systematically, (3) obtaining high learning outcomes, (4) training students in communicating ideas, especially in writing scientific papers, and (5) developing student characters ${ }^{18}$.

14 Abu Maskur \& Puji Anto, 'Metode Pembelajaran Bahasa Asing Arab di Pondok Pesantren Modern (Studi Kasus di Pondok Pesantren Roudlotul Qurro Cirebon)', El Banar: Jurnal Pendidikan dan Pengajaran, 2018, 1(1).

15 Abd. Rozak, 'Modernisme Pembelajaran Bahasa Arab Berbasis Pesantren di Rangkasbitung Banten', Arabi: Journal of Arabic Studies, 2018, 3(2); Ismail Suardi Wekke, 'Arabic Teaching and Learning on Construction of Modern Instruction in Muslim Minority Pesantren Society', Edukasia Islamika, 2018, 3(1).

${ }^{16}$ M. Hosnan, Pendekatan Saintifik dan Kontekstual dalam Pembelajaran Abad 21 (Jakarta: Ghalia Indonesia, 2014), page. 34.

17 Abdul Majid, Pembelajaran Tematik Terpadu (Bandung: PT Remaja Rosdakarya, 2014), page. 193.

${ }^{18}$ Bambang Prihadi, Penerapan langkah-Langkah Pembelajaran dengan Pendekatan Saintifik dalam Kurikulum 2013, Makalah, In House Traning Implementasi Kurikulum 2013 di SMPN 8 Kota Pekalongan, 2014. 
The application of approaches in learning in Indonesia is currently directed to empower all potentials possessed by students so that they can have the competencies expected through efforts to grow and develop attitudes, knowledge, and skills ${ }^{19}$. The whole learning will give birth to personal qualities that are productive, creative, innovative, and affective which reflect the integrity of the mastery of integrated attitudes, knowledge and skills ${ }^{20}$.

Learning process with a scientific approach is carried out guided by scientific values, principles, or criteria. The learning process is called scientific if it meets the following criteria ${ }^{21}$ :

1. Learning material that based on facts or phenomena that can be explained with logic or reasoning.

2. Teacher's explanation, students' responses, and educative interactions of the teacher participants are free from prejudice, subjective thinking, or reasoning that deviates from logic.

3. Encouraging and inspiring students to think critically, analysis and appropriately.

4. Encouraging and inspiring students to be able to think hypothetically in seeing differences, similarities, and links, with each other from the learning material.

5. Encouraging students to be able to understand, apply, and develop rational and objective mindsets.

6. Based on concepts, theories, and empirical facts that can be accounted for.

7. Learning objectives are formulated simply and clearly.

The scientific approach is closely related to the scientific method. Scientific methods generally involve the observational activities needed to formulate hypotheses or collect data. As for the elements of a scientific approach to learning, including: digging information through observation (asking observing), asking questions (questioning), gathering information/trying (experimenting), analyzing/reasoning (associating), and communicating by forming networks (networking) ${ }^{22}$. Thus, that learning with a scientific approach is a learning process designed in such a way that students actively construct

\footnotetext{
${ }^{19}$ M. Hosnan, Pendekatan Saintifik ..., page. 34.

${ }^{20}$ Permendikbud Nomor 67 Tahun 2013 tentang Kerangka Dasar dan Struktur Kurikulum Sekolah Dasar/Madrasah Ibtidaiyah.

21 Abdul Majid \& Chaerul Rochman, Pendekatan Ilmiah dalam Implementasi Kurikulum 2013 (Bandung: PT Remaja Rosdakarya, 2014), page. 70.

${ }^{22}$ Permendikbud Nomor 81A Tahun 2013 tentang Implementasi Kurikulum: Pedoman Umum Pembelajaran.
} 
concepts, laws or principles through stages of observing, formulating problems, proposing or formulating hypotheses, collecting data with various techniques, analyzing data, attracting conclusions and communicate the concepts, laws or principles found ${ }^{23}$.

Meanwhile, the Ministry of Education and Culture ${ }^{24}$ explains the five steps in the learning process that refer to the scientific approach, namely: observing, asking questions, collecting data, associating, and communicating. Next explained as follows.

1. Observing, namely student activities identify through the sense of sight (reading, listening), smell, listener, taste and touch when observing an object with or without tools. Alternative observing activities include environmental observation, observing images, videos, tables and graphs of data, analyzing maps, reading various information available in the mass media and the internet as well as other sources. The form of learning outcomes from observing activities is that students can identify problems.

2. Asking questions, namely students' activities expressing what they want to know both regarding an object, event, a certain process. In the questioning activity, students make individual or group questions about what they don't know yet. Students can ask questions to the teacher, resource persons, other students and or to themselves with the guidance of the teacher so that students can be independent and become habits. Questions can be asked verbally and in writing and should be able to arouse students' motivation to stay active and happy. The form can be a question sentence and a hypothesis sentence. The learning outcomes of the questioning activity are students being able to formulate problems and formulate hypotheses.

3. Collecting data, i.e. activities of students looking for information as material to be analyzed and concluded. Data collection activities can be done by reading books, collecting secondary data, field observations, trials (experiments), interviews, distributing questionnaires, and others. The learning outcomes of data gathering activities are students can test hypotheses.

4. Associating, namely student activities to process data in the form of a series of physical and mind activities with the help of certain equipment. Forms of data processing activities include classifying, sorting, calculating, dividing, and page. 51 .

${ }^{23}$ Daryanto, Pendekatan Pembelajaran Saintifik Kurikulum 2013 (Yogyakarta: Gava Media, 2014), 
compiling data in a more informative form, and determining data sources so that they are more meaningful. Student activities in processing data for example making tables, graphs, charts, concept maps, counting, and modeling. Next students analyze the data to compare or determine the relationship between the data that has been processed with existing theories so that conclusions can be drawn and / or the discovery of important principles and concepts that are meaningful in adding cognitive schemes, expanding experiences, and knowledge insights. Learning outcomes from reasoning / associating activities are students can conclude the results of the study of the hypothesis.

5. Communicating, namely student activities describing and conveying their findings from observing, questioning, collecting and processing data, and associating aimed at others both verbally and in writing in the form of diagrams, charts, pictures, and the like with the help of simple technological devices and or information and communication technology. The learning outcomes of communicating activities are students can formulate and account for the verification of hypotheses.

Based on the opinions of the experts above, it can be concluded that the scientific approach is a student-centered approach. Therefore, students actively construct concepts, laws or principles through stages of observing, formulating problems, proposing or formulating hypotheses, collecting data with various techniques, analyzing data, attracting conclusions and communicate the concepts, laws or principles found.

\section{Learning Arabic in Islamic Boarding Schools}

As a living language, Arabic has an important role in the fields of religion (Islam), science, and international relations. His role is also very important in fostering and developing national culture ${ }^{25}$. Therefore, learning Arabic in educational institutions in Indonesia becomes very important, for Muslims in particular and for the people of Indonesia in general. According to Hermawan ${ }^{26}$, there are at least four orientations in Arabic education, namely:

a. Religious orientation, namely learning Arabic for the purpose of understanding and comprehending Islamic teachings.

\footnotetext{
${ }^{24}$ Kemdikbud, Materi Pelatihan Implementasi Kurikulum 2013 (Jakarta: Kemdikbud, 2016).

${ }^{25}$ Ahmad Izzan, Metodologi Pembelajaran Bahasa Arab (Bandung: Humaniora 2009), page 46-60.

26 Acep Hermawan, Metodologi Pembelajaran Bahasa Arab (Bandung: PT Remaja Rosdakarya, 2011), page 89 .
} 
b. Academic orientation, which is learning Arabic for the purpose of understanding Arabic sciences and skills.

c. Professional, practical and pragmatic orientation, namely learning Arabic for professional, practical or pragmatic purposes.

d. Ideological and economic orientation, namely learning Arabic to understand and use Arabic as a medium for the interests of orientalism, capitalism, imperialism, and so on.

The methodology of teaching Arabic in Indonesia develops as the role and needs of the Arabic language develop. According to Muna ${ }^{27}$, the development of the methodology of teaching Arabic in Indonesia can be described as follows:

1. Arabic language entered Indonesia at the same time as Islam, the first Arabic lesson in Indonesia was to meet the needs of a Muslim in performing worship. The material taught also revolves around the reading of prayer, prayers, and recitation of the letters of the Qur'an with the method of abjadiyah (alphabetic method).

2. Learning Arabic in the form of deepening Islamic teachings. Learning Arabic is emphasized in the mastery of nahw and sharf (grammar). In his teaching the qawa'id wa tarjamah (grammar translation) method is used

3. At the beginning of the 19th century, in learning Arabic in Indonesia, in several modern Islamic universities began to apply the Tariqah Mubasyirah (direct method).

4. Forms of language teaching found in formal educational institutions, in this case madrassas and public schools after the era of independence. Some of the methods used are mimicry-memorization, pattern-practice, and what is new is the active learning method.

Based on the description above, it can be concluded that the first goal of learning Arabic in Indonesia is to meet the needs of a Muslim in worship. In accordance with these needs, the material taught is prayer prayers and short letters in the Qur'an which are commonly called juz amma. If we see this first form of learning from a philosophical approach then surely there is no explicit written purpose that can be found. A person learns Arabic solely because of religious motives. However, implicitly there is a clear

27 Wa Muna, Metodologi Pembelajaran Bahasa Arab: Teori dan Aplikasi (Yogyakarta: Teras, 2011), page 20-24. 
purpose, namely Arabic as a means of worship. The verbalistic teaching of Arabic is deemed insufficient, because the Qur'an is not enough to be read only as a means of worship, but rather a way of life that must be understood by its teachings and practiced. Then came the second form of teaching Arabic language with the aim of deepening the teachings of Islam. The subject matter taught is diverse. Learning Arabic in this form grows and develops in Islamic boarding schools.

Islamic boarding schools is one of the oldest Islamic education institutions in Indonesia. Education in Islamic boarding schools includes Islamic education, $d a^{\prime} w a h$, community development and other similar education ${ }^{28}$. Islamic boarding schools in Indonesia are a form of traditional education institutions that are still relevant and still exist today. Since the change or modernization of Islamic education was launched in various regions of the Islamic world, not many traditional Islamic educational institutions such as Islamic boarding schools have survived. Most of them have been displaced by the expansion of the secular education system or have been transformed into public education institutions, or at least adjusted and adopted the contents and methodologies of secular public education ${ }^{29}$.

Arabic is an important subject in Islamic boarding schools. In this case, Islamic boarding schools can be classified into two groups, namely (1) Islamic boarding schools which provide students more with knowledge about language, especially vocabulary and grammar and (2) boarding schools which provide students with language skills. Islamic boarding schools which provide many students with knowledge of Arabic vocabulary and grammar direct their learning to form students who are able to understand religious texts in depth. Islamic boarding schools which are more equipped their students with language skills, direct their learning to form students' skills in using Arabic to communicate, both in receptive and active forms.

Each of the groups above has advantages and disadvantages. Learning Arabic language oriented to knowledge about language, is able to form students who are very masters of vocabulary and understand Arabic grammar in depth so that they are able to understand texts and analyze their sentence structure in detail, but have difficulty in applying this knowledge when having to communicate using language. Learning Arabic

28 Direktorat Jenderal Kelembagaan Islam Departemen Agama RI, Pondok Pesantren dan Madrasah Diniyah (Jakarta: Departemen Agama RI, 2003), page 1.

${ }^{29}$ Tim Pengembang Ilmu Pendidikan, Ilmu dan Aplikasi Pendidikan (Bandung: PT Imperial Bhakti Utama, 2007), page 437-438. 
which is oriented to the formation of language skills, is able to form students who are skilled in using Arabic to communicate, without too much questioning the truth from grammatical aspects.

\section{Method}

The research method used was a survey method. The research was conducted at the province of West Sumatra at the first semester of the cademic year 2019. The research sample consisted of 20 Islamic boarding schools in the province of West Sumatra. Research data were collected through a questionnaire. The questionnaire was filled out by the teacher who teach Arabic subjects in Islamic boarding schools. The questionnaire asked teachers' responses to questions related to their perception of application of scientific approaches in learning of Arabic in Islamic boarding school. The data analysis technique is descriptive quantitative analysis using percentages.

\section{Result and Discussion}

Based on the research that has been done, the researcher obtained data related to teacher's perception of the application of scientific approaches in learning of Arabic in Islamic boarding schools in West Sumatra as follows.

Table 1. Application of Scientific Approaches in Learning of Arabic

\begin{tabular}{clcc}
\hline No & \multicolumn{1}{c}{ Response } & Frequency & Percentage \\
\hline 1 & Strongly agree & 9 & $45 \%$ \\
2 & Agree & 10 & $50 \%$ \\
3 & Somewhat disagree & 1 & $5 \%$ \\
4 & Disagree & 0 & $0 \%$ \\
\hline
\end{tabular}

Based on the results of research on teacher perceptions of the application of scientific approaches in learning of Arabic in Islamic boarding schools, the data obtained as shown in the table. Based on the table above, it can be concluded that 9 teachers (45 percent) strongly agreed with the statement, 10 teachers (50 percent) agreed, 1 teacher (5 percent) somewhat disagreed, and none of teachers disagreed with the statement.

Table 2. The Steps of Scientific Approach are Appropriate for Arabic Learning

\begin{tabular}{clcc}
\hline No & \multicolumn{1}{c}{ Response } & Frequency & Percentage \\
\hline 1 & Strongly agree & 8 & $40 \%$ \\
2 & Agree & 10 & $50 \%$ \\
3 & Somewhat disagree & 2 & $10 \%$ \\
\hline
\end{tabular}




\begin{tabular}{llll}
\hline 4 & Disagree & 0 & $0 \%$ \\
\hline
\end{tabular}

The results of research on teacher perceptions of the appropriately of the scientific approach for Arabic learning showed that 8 teachers (40 percent) strongly agreed with the statement, 10 teachers (50 percent) agreed, 2 teachers (10 percent) somewhat disagreed, and there were no teachers who answered that they did not agree with the statement.

Table 3. Scientific Approach is Effective for Achieving Arabic Learning Outcomes

\begin{tabular}{clcc}
\hline No & \multicolumn{1}{c}{ Response } & Frequency & Percentage \\
1 & Strongly agree & 8 & $40 \%$ \\
2 & Agree & 10 & $50 \%$ \\
3 & Somewhat disagree & 2 & $10 \%$ \\
4 & Disagree & 0 & $0 \%$ \\
\hline
\end{tabular}

Based on the results of research on teacher perceptions of the effectively of scientific approach for achieving Arabic learning outcomes, it can be found that 8 teachers (40 percent) strongly agreed with the statement, 10 teachers (50 percent) agreed, 2 teachers (10 percent) somewhat disagreed, and none of teachers disagreed with the statement.

Table 4. The Scientific Approach is better than other Approaches for Arabic Learning

\begin{tabular}{clcc}
\hline No & \multicolumn{1}{c}{ Response } & Frequency & Percentage \\
\hline 1 & Strongly agree & 7 & $35 \%$ \\
2 & Agree & 12 & $60 \%$ \\
3 & Somewhat disagree & 1 & $5 \%$ \\
4 & Disagree & 0 & $0 \%$ \\
\hline
\end{tabular}

Based on data above, it can be found that 7 teachers (35 percent) strongly agreed that the scientific approach is better than other approaches for Arabic learning, 12 teachers (60 percent) agreed, 1 teacher (5 percent) somewhat disagreed, and there were no teachers who answered that they did not agree with the statement.

Table 5. The Steps of Scientific Approach are Easy to Apply in Arabic Learning

\begin{tabular}{clcc}
\hline No & \multicolumn{1}{c}{ Response } & Frequency & Percentage \\
\hline 1 & Strongly agree & 4 & $20 \%$ \\
2 & Agree & 12 & $60 \%$ \\
3 & Somewhat disagree & 4 & $20 \%$ \\
4 & Disagree & 0 & $0 \%$ \\
\hline
\end{tabular}


The data on teacher perceptions of the easily of the steps of scientific approach to apply in Arabic learning showed that 4 teachers (20 percent) strongly agreed with the statement, 12 teachers (60 percent) agreed, 4 teachers (20 percent) somewhat disagreed, and there were no teachers who answered that they did not agree with the statement.

Table 6. The Teachers Receive Sufficient Training to Apply Scientific Approach in Arabic Learning

\begin{tabular}{clcc}
\hline No & \multicolumn{1}{c}{ Response } & Frequency & Percentage \\
\hline 1 & Strongly agree & 9 & $45 \%$ \\
2 & Agree & 9 & $45 \%$ \\
3 & Somewhat disagree & 2 & $10 \%$ \\
4 & Disagree & 0 & $0 \%$ \\
\hline
\end{tabular}

Based on the results of research on teacher perceptions of receiving sufficient training to apply scientific approach in Arabic learning, it can be concluded that 9 teachers (45 percent) strongly agreed with the statement, 9 teachers (45 percent) agreed, 2 teachers (5 percent) somewhat disagreed, and none of teachers disagreed with the statement.

Table 7. The Scientific Approach is Easy to Apply Through Existing Learning Models and Methods

\begin{tabular}{clcc}
\hline No & \multicolumn{1}{c}{ Response } & Frequency & Percentage \\
\hline 1 & Strongly agree & 9 & $45 \%$ \\
2 & Agree & 9 & $45 \%$ \\
3 & Somewhat disagree & 2 & $10 \%$ \\
4 & Disagree & 0 & $0 \%$ \\
\hline
\end{tabular}

The results of research on teacher perceptions of the easyly of the scientific approach to apply through existing learning models and methods for Arabic learning showed that 9 teachers (45 percent) strongly agreed with the statement, 9 teachers (45 percent) agreed, 2 teachers (10 percent) somewhat disagreed, and there were no teachers who answered that they did not agree with the statement.

Table 8. The Teachers Found Difficulties in Applying The Scientific Approach in Arabic Learning

\begin{tabular}{clcc}
\hline No & Response & Frequency & Percentage \\
\hline 1 & Strongly agree & 1 & $5 \%$ \\
2 & Agree & 9 & $45 \%$ \\
3 & Somewhat disagree & 8 & $40 \%$ \\
4 & Disagree & 2 & $10 \%$ \\
\hline
\end{tabular}

Based on the results of research on teacher perceptions of the difficulties of the teachers in applying the scientific approach in Arabic learning, it can be found that 1 
teacher ( 5 percent) strongly agreed with the statement, 9 teachers ( 45 percent) agreed, 8 teachers (40 percent) somewhat disagreed, and 2 teachers (10 percent) disagreed with the statement.

Table 9. The Students Found Difficulties in Understanding Arabic Materials Taught Through The Scientific Approach

\begin{tabular}{clcc}
\hline No & \multicolumn{1}{c}{ Response } & Frequency & Percentage \\
\hline 1 & Strongly agree & 2 & $10 \%$ \\
2 & Agree & 6 & $30 \%$ \\
3 & Somewhat disagree & 10 & $50 \%$ \\
4 & Disagree & 2 & $10 \%$ \\
\hline
\end{tabular}

Based on data on the difficulties of the students in understanding Arabic materials taught through the scientific approach, it can be found that 2 teachers (10 percent) strongly agreed, 6 teachers (30 percent) agreed, 10 teachers (50 percent) somewhat disagreed, and 2 teachers (10 percent) did not agree with the statement.

Table 10. The Available Infrastructure in The Schools Supports The Application of The Scientific Approach in Arabic Learning

\begin{tabular}{clcc}
\hline No & Response & Frequency & Percentage \\
\hline 1 & Strongly agree & 4 & $20 \%$ \\
2 & Agree & 8 & $40 \%$ \\
3 & Somewhat disagree & 4 & $20 \%$ \\
4 & Disagree & 4 & $20 \%$ \\
\hline
\end{tabular}

The data on teacher perceptions of the supporting of available infrastructure in the schools for applying scientific approach in Arabic learning showed that 4 teachers (20 percent) strongly agreed with the statement, 8 teachers (40 percent) agreed, 4 teachers (20 percent) somewhat disagreed, and 4 teachers (20 percent) answered that they did not agree with the statement.

Based on the description of the data above, it can be concluded that the majority of Arabic teachers in Islamic boarding schools agreed with the application of scientific approach in learning Arabic in Islamic boarding schools. In addition, according to the teacher, a scientific approach is appropriate to be used in learning Arabic, it is effective to improve Arabic learning outcomes of the students, and the steps are fairly easy to be implemented. The teacher also perceive that the scientific approach is easy to apply through existing language learning models and methods, so that the teacher can modify the learning to be more interesting and exciting. 
However, based on the data above, although teachers have received training in implementation of a scientific approach in learning Arabic, teachers still find difficulties in practicing in the classroom. Because of that, more intensive training is needed, especially for Arabic teachers of Islamic boarding school. This is in accordance with the results of the research of Suyanto ${ }^{30}$ which also concluded that teachers still need training in order to implement the scientific learning process in accordance with scientific steps.

Some teachers perceive that students also find difficulties in learning Arabic using a scientific approach. Indeed the scientific learning process requires special skills from the teachers in teaching, so that they can help the students in understanding the lesson. In addition, some teachers also perceive that not all of Islamic boarding schools have adequate facilities and infrastructures to support the implementation of a scientific approach. In fact, the problem of the lack of these facilities is not only faced by pesantren but also by schools/madrasah's.

\section{Conclusion}

Based on the results of the research, it can be concluded that the majority of Arabic teachers in the Islamic boarding schools agree with the application of the scientific approach. It's just that more intensive training is needed, especially for Islamic boarding school teachers, because training in the implementation of the scientific approach involves more Arabic teachers in schools/madrasah's, while there are so few Arabic boarding school teachers involved in training. Therefore, it is needed a policy from the authorities to improve the competence of Arabic teachers in Islamic boarding schools, especially related to the implementation of the scientific approach. Learning Arabic is not new in Islamic boarding schools. Arabic has been taught in Islamic boarding schools in Indonesia for years, so that in the history of learning Arabic in Indonesia, it has been noted that various approaches have been used. Therefore, a scientific approach is a form of enlightenment for learning Arabic in Islamic boarding schools today. The application of this scientific approach is expected to improve the quality of learning and learning outcomes in Arabic at Islamic boarding schools. It is recommended to further researchers to conduct research related to the implementation of scientific approach in learning Arabic in Islamic boarding schools.

${ }^{30}$ Slamet Suyanto, 'The Implementation of the Scientific Approach through 5Ms of the Revised Curriculum 2013 in Indonesia', Cakrawala Pendidikan, 2018, 37(1). 


\section{Acknowledgment}

We would like to express our sincere appreciation to the teachers of Islamic boarding schools in the province of West Sumatra for their information. We would also like to show our gratitude to IAIN Batusangkar for the support for the publication of this research report.

\section{References}

Adnyani, K. E. K., Mahayanti, N. W. S., \& Suprianti, G. A. P. (2015). Persepsi Guru Bahasa Jepang di Kabupaten Buleleng Terhadap Penerapan Pendekatan Saintifik dalam Implementasi Kurikulum 2013. SEMINAR NASIONAL RISET INOVATIF III, 8-13. Singaraja Bali: Lembaga Penelitian Universitas Pendidikan Ganesha.

Ahmad, D., \& Mardiana. (2014). Kurikulum 2013 dalam Persepsi dan Interpretasi Guru Bahasa Inggris SMA Kota Makassar. BAHTERA: Jurnal Pendidikan Bahasa dan Sastra, 13(1), 73-80.

Ainin, M. (2017). Implementasi Pendekatan Saintifik di Era Kurikulum URIKULUM 13 dalam Pembelajaran Bahasa Arab: Relevankah? Konferensi Nasional Bahasa Arab III, 377-385. Malang.

Albantani, A. M. (2015). Implementasi Kurikulum 2013 pada Pembelajaran Bahasa Arab di Madrasah Ibtidaiyah. Arabiyat: Jurnal Pendidikan Bahasa Arab dan Kebahasaaraban, 2(2), 178-191. https://doi.org/10.15408/a.v2i2.2127

Atmarizon, D., \& Zaim, M. (2016). The Implementation of Scientific Approach in Teaching English at the Tenth Grade of Senior High School 7 Padang. Komposisi: Jurnal Pendidikan Bahasa, Sastra, dan Seni, 17(1), 1-18. https://doi.org/10.24036/komposisi.v17i1.8113

Daryanto. (2014). Pendekatan Pembelajaran Saintifik Kurikulum 2013. Yogyakarta: Gava Media.

Direktorat Jenderal Kelembagaan Islam Departemen Agama RI. (2003). Pondok Pesantren dan Madrasah Diniyah. Jakarta: Departemen Agama RI.

Firman, Baedhowi, \& Murtini, W. (2018). The Effectiveness of The Scientific Approach to Improve Student Learning Outcomes. International Journal of Active Learning, 3(2), 86-91. Retrieved from http://journal.unnes.ac.id/nju/index.php/ijal\%0AThe

Hanani, N. (2015). Model Pembelajaran Bahasa Arab di Pondok Pesantren Salaf Kediri dan Kontribusinya terhadap Kemampuan Membaca Teks Berbahasa Arab bagi Santri. Realita, 13(1), 81-96.

Hermawan, A. (2011). Metodologi Pembelajaran Bahasa Arab. Bandung: PT Remaja Rosdakarya.

Hosnan, M. (2014). Pendekatan Saintifik dan Kontekstual dalam Pembelajaran Abad 21. 
Jakarta: Ghalia Indonesia.

Indriawan, R., Slamet, A., \& Kardoyo. (2018). Implementation of Scientific Approach in Economic Learning. Journal of Economic Education, 7(1), 18-23. https://doi.org/10.15294/jeec.v7i1.22418

Izzan, A. (2009). Metodologi Pembelajaran Bahasa Arab. Bandung: Humaniora.

Kawuryan, S. P., Hastuti, W. sri, \& Supartinah. (2018). Pengaruh Model Pembelajaran Tematik Berbasis Permainan Tradisional dan Scientific Approach terhadap Kemampuan Berpikir Kreatif. Cakrawala Pendidikan, 37(1), 71-84.

Kemdikbud. (2016). Materi Pelatihan Implementasi Kurikulum 2013. Jakarta: Kemdikbud.

Khoirunnisak, B. (2016). Implementasi Pendidikan Saintifik dalam Pembelajaran Bahasa Arab. Al Mahāra Jurnal Pendidikan Bahasa Arab, 2(1), 95-118.

Majid, A. (2014). Pembelajaran Tematik Terpadu. Bandung: PT Remaja Rosdakarya.

Majid, A., \& Rochman, C. (2014). Pendekatan Ilmiah dalam Implementasi Kurikulum 2013. Bandung: PT Remaja Rosdakarya.

Maskur, A., \& Anto, P. (2018). Metode Pembelajaran Bahasa Asing Arab di Pondok Pesantren Modern (Studi Kasus di Pondok Pesantren Roudlotul Qurro Cirebon). El Banar: Jurnal Pendidikan dan Pengajaran, 1(1), 63-68. Retrieved from http://ojs.staibanisaleh.ac.id/index.php/ElBanar/article/view/10

Muna, W. (2011). Metodologi Pembelajaran Bahasa Arab: Teori dan Aplikasi. Yogyakarta: Teras.

Ningrum, E. (2019). Mapping of Pedagogic Competency of Geography Teacher in Scientific Learning Based-On Curriculum 2013. IOP Conference Series: Earth and Environmental Science, 286(1), 1-5. https://doi.org/10.1088/1755$1315 / 286 / 1 / 012007$

Permendikbud Nomor 67, 2013a, tentang Kerangka Dasar dan Struktur Kurikulum Sekolah Dasar/Madrasah Ibtidaiyah.

Permendikbud Nomor 81A, 2013b, tentang Implementasi Kurikulum: Pedoman Umum Pembelajaran.

Purnamaningwulan, R. A. (2019). Pre-Service Teachers' Reflective Practices in Implementation the Scientific Aproach of 2013 Curriculum. International Journal of Indonesian Education and Teaching, 3(2), 157-168. https://doi.org/10.24070/ijiet.2019.030104

Prihadi, B. (2014). Penerapan langkah-Langkah Pembelajaran dengan Pendekatan Saintifik dalam Kurikulum 2013. Makalah. In House Traning Implementasi Kurikulum 2013 di SMPN 8 Kota Pekalongan, 23-24 Mei 2014. 
Ratnaningsih, S. (2017). Scientific Approach of 2013 Curriculum: Teachers' Implementation in English Language Teaching. English Review: Journal of English Education, 6(1), 33-40. https://doi.org/10.25134/erjee.v6i1.792

Rozak, A. (2018). Modernisme Pembelajaran Bahasa Arab Berbasis Pesantren di Rangkasbitung Banten. Arabi: Journal of Arabic Studies, 3(2), 167-180. https://doi.org/10.24865/ajas.v3i2.110

Sadat, A. (2017). Pendekatan Saintifik dalam Pembelajaran Bahasa Arab di Madrasah Ibtidaiyah Berbasis Kurikulum 2013. EL-Muhbib: Jurnal Pemikiran dan Penelitian Pendidikan Dasar, 1(2), 80-96.

Safitri, R. E., \& Widjajanti, D. B. (2019). The Effect of Inquiry in Scientific Learning on Students' Self-Confidence. Journal of Physics: Conference Series, 1157(4). https://doi.org/10.1088/1742-6596/1157/4/042073

Setiawan, D., \& Wilujeng, I. (2016). The Development of Scientific-Approach-Based Learning Instruments Integrated with Red Onion Farming Potency in Brebes Indonesia. Jurnal Pendidikan IPA Indonesia, 5(1), 22-30. https://doi.org/10.15294/jpii.v5i1.5785

Susanti, R., Anwar, Y., \& Ermayanti. (2019). Implementation of Learning Based on Scientific Approach to Improve Science Process Skills of Biology Education Students in General Biology Course. Journal of Physics: Conference Series, 1166(1). https://doi.org/10.1088/1742-6596/1166/1/012004

Susantini, E., Kurniasari, I., Fauziah, A. N. M., Prastowo, T., Kholiq, A., \& Rosdiana, L. (2018). Engaging Pre-Service Teachers to Teach Science Contextually with Scientific Approach Instructional Video. IOP Conference Series: Materials Science and Engineering, 296. https://doi.org/10.1088/1757-899x/296/1/012053

Suyanto, S. (2018). The Implementation of the Scientific Approach through 5Ms of the Revised Curriculum 2013 in Indonesia. Cakrawala Pendidikan, 37(1), 22-29.

Tim Pengembang Pendidikan. (2007). Ilmu dan Aplikasi Pendidikan. Bandung: PT Imperial Bhakti Utama.

Wahyono, Abdulhak, I., \& Rusman. (2017). Implementation of Scientific Approach Based Learning to Think High Levels in State Senior High School in Ketapang. International Journal of Education and Research, 5(8), 221-230. Retrieved from www.ijern.com

Wekke, I. S. (2018). Arabic Teaching and Learning on Construction of Modern Instruction in Muslim Minority Pesantren Society. Edukasia Islamika, 3(1), 32. https://doi.org/10.28918/jei.v3i1.1677

Yanti, P. G., Ibrahim, N., \& Rahman, F. (2018). Persepsi Guru terhadap Pendekatan Saintifik pada Kurikulum 2013 dalam Proses Belajar Mengajar. Faktor: Jurnal Ilmiah Kependidikan, 5(1), 29-34.

Zaim, M. (2017). Implementing Scientific Approach to Teach English at Senior High 
School in Indonesia. Asian Social Science, 13(2), 33-40. https://doi.org/10.5539/ass.v13n2p33 